\title{
ANALISIS STRUKTUR PERILAKU DAN KINERJA PASAR (STRUCTURE, CONDUCT AND MARKET PERFORMAN) KOMODITI PADI DI DESA BUNGA RAYA DAN DESA KEMUNING MUDA KECAMATAN BUNGA RAYA KABUPATEN SIAK
}

\author{
Novia Dewi ${ }^{2}$,Jum'atri Yusri' ${ }^{2}$ Ari Jolanda Saputra ${ }^{1}$ \\ 1) Mahasiswa Jurusan Agribisnis, Fakultas Pertanian, Universitas Riau. \\ 2) Staf pengajar Jurusan Agribisnis, Fakultas Pertanian, Universitas Riau. \\ JL. HR. Soebrantas. Km 12. Kode Pos 28293, Pekanbaru \\ Email : dewinovia642@gmail.com
}

\begin{abstract}
ABSTRAK
Penelitian ini bertujuan untuk menganalisis struktur, perilaku, dan kinerja pemasaran beras di Kabupaten Bunga Raya. Lokasi penelitian ditentukan dengan menggunakan metode purpossive sampling yaitu dua desa menjadi sentra produksi padi. Responden penelitian adalah petani padi dan semua agensi pemasaran yang terlibat dalam pemasaran beras dari petani sebagai produsen ke pedagang besar sebagai konsumen. Hasil penelitian menunjukkan ada tiga saluran pemasaran beras yaitu saluran pemasaran I petani menjual kepada pedagang pengumpul dan kemudian dijual ke pedagang besar, saluran pemasaran II petani menjual ke pedagang pengumul yang memiliki penggilingan padi kemudian dijual ke pedagang grosir dan saluran pemasaran III yaitu petani menjual langsung ke pedagang grosir. Struktur pasar beras adalah pasar oligopsoni karena dilihat dari jumlah pembeli yang relatif sangat sedikit, kemudian dilihat dari nilai market share, rasio konsentrasi dan indeks Herfindahl dari pedagang manapun menunjukkan nilai yang tidak terlalu berbeda. Petani sebagai produsen adalah penerima harga (price taker), dimana petani sebagai produsen mendapatkan perubahan nilai harga lebih kecil dibandingkan dengan pedagang grosir sebagai konsumen. Margin pemasaran terlihat dari setiap saluran pemasaran yang terjadi menunjukkan bahwa margin dan keuntungan paling banyak didapat oleh pedagang yang melakukan lebih banyak fungsi pemasaran.
\end{abstract}

Kata Kunci: Struktur, Perilaku, Kinerja, Pasar, Padi

\section{PENDAHULUAN}

Salah satu kabupaten yang memasarkan hasil produksi padinya adalah Kabupaten Siak, di Kabupaten Siak tanaman padi khususnya padi sawah merupakan salah satu tanaman yang cocok untuk dikembangkan di daerah ini, terbukti dengan menempatkan Kabupaten Siak dalam salah satu kabupaten dengan produksi dan luas panen terbesar di Provinsi Riau pada tahun 2014. Produksi padi sawah tertinggi di Kabupaten Siak terdapat pada Kecamatan Bunga Raya. Produksi padi sawah di Kecamatan Bunga Raya pada tahun 2014 sebesar 22.819,25 ton dengan luas panen

42 Analisis Struktur Perilaku Dan Kinerja Pasar (Structure, Conduct And Market Performan) Komoditi Padi Di Desa Bunga Raya Dan Desa Kemuning Muda Kecamatan Bunga Raya Kabupaten Siak 
sebesar 4.408 ha. Data luas tanam, luas panen dan produksi padi sawah di Kabupaten Siak dapat dilihat pada Tabel 1.

Tabel 1.Luas tanam, luas panen dan produksi padi sawah di Kabupaten Siak Tahun 2014

\begin{tabular}{|c|c|c|c|c|}
\hline No & Kecamatan & Luas Tanam (Ha) & Luas Panen (Ha) & Produksi $(\mathrm{Ha})$ \\
\hline 1 & Siak & - & - & - \\
\hline 2 & Bunga Raya & 4.408 & 4.020 & $22.819,25$ \\
\hline 3 & Sungai Apit & 553 & 631 & $2.777,31$ \\
\hline 4 & Dayun & - & - & - \\
\hline 5 & Koto Gasip & - & - & - \\
\hline 6 & Kandis & 110 & 68 & 280,95 \\
\hline 7 & Minas & - & - & - \\
\hline 8 & Kerinci Kanan & - & - & - \\
\hline 9 & Tualang & - & - & - \\
\hline 10 & Sungai Mandau & 1.188 & 1.136 & $5.776,80$ \\
\hline 11 & Lubuk Dalam & - & - & - \\
\hline 12 & Mempura & - & - & - \\
\hline 13 & Sabak Auh & 1.380 & 1.895 & $8.739,80$ \\
\hline 14 & Pusako & 30 & - & - \\
\hline \multicolumn{2}{|c|}{ Jumlah } & 7.669 & 7.751 & $40.394,11$ \\
\hline
\end{tabular}

Sumber : Dinas Tanaman Pangan dan Hortikultura Kabupaten Siak 2015

Luas panen dan produktivitas tanaman merupakan faktor utama dalam meningkatkan produksi padi. Dengan tingkat produksi yang begitu besar ternyata tidak diimbangi dengan harga jual yang memadai sehingga pendapatan para petani masih relatif rendah sebagai akibat dari pembentukan harga beras yang kurang transparan oleh pelaku pasar yang terlibat dalam pemasaran padi.

Pemerintah telah menetapkan kebijakan harga dasar gabah sebagai patokan yang dapat diterima oleh petani. Kebijakan tersebut dijelaskan dalam instruksi presiden (Inpres) penetapan harga pembelian pemerintah (HPP). Inpres Nomor 5 tahun 2015 menetapkan tentang ketentuan harga pembelian pemerintah (HPP) untuk gabah kering panen (GKP) dari Rp 3.300 per kilogram menjadi Rp 3.700 per kilogram di tingkat petani, untuk gabah kering giling (GKG) Rp 4.150 per kilogram menjadi Rp 4.600 per kilogram ditingkat penggilingan, sedangkan untuk harga beras naik dari Rp 6.600 per kilogram menjadi Rp 7.300 per kilogram di Perum Bulog (Anonim, 2016).

43 Analisis Struktur Perilaku Dan Kinerja Pasar (Structure, Conduct And Market Performan) Komoditi Padi Di Desa Bunga Raya Dan Desa Kemuning Muda Kecamatan Bunga Raya Kabupaten Siak 
Lembaga pemasaran yang terlibat juga mempengaruhi harga yang akan diterima oleh para petani padi. Semakin banyak lembaga pemasaran yang terlibat dalam pemasaran hasil produksi maka semakin rendah harga yang akan diterima oleh para petani. Hal ini sejalan dengan Syahza (2003), yang menyatakan disparitas antara harga gabah dan beras yang tinggi merupakan akibat dari panjangnya saluran maupun rantai pemasaran komoditas pertanian. Keadaan ini akan menyebabkan besarnya biaya distribusi margin pemasaran yang tinggi. Sehingga adanya bagian yang harus dikeluarkan sebagai keuntungan pedagang. Pada umumnya petani tidak terlibat dalam saluran pemasaran produk, sehingga nilai tambah pengolahan dan perdagangan produk pertanian hanya dinikmati oleh pedagang.Penelitian ini bertujuan untuk menganalisis struktur, perilaku dan kinerja pasar padi di Kecamatan Bunga Raya Kabupaten Siak.

\section{METODE PENELITIAN}

\section{Tempat dan Waktu Penelitian}

Penelitian ini dilaksanakan di Desa Bunga Raya dan Desa Kemuning Muda Kecamatan Bunga Raya Kabupaten Siak pada Bulan April-Juni 2016. Lokasi penelitian ditentukan secara purposive dimana Desa Bunga Raya dan Desa Kemuning Muda adalah desa sentra produksi padi di Kecamatan Bunga Raya Kabupaten Siak.

\section{Metode Pengambilan Sampel dan Data}

Penelitian ini menggunakan metode survei. Objek dari penelitian ini adalah petani padi dan lembaga pemasaran yang terlibat dalam pemasaran padi dari produsen ke konsumen. Jumlah sampel sebanyak 36 petani ditiap desa dengan luas lahan minimal 1 hektar. Sementara untuk lembaga pemasaran padi di Desa Bunga Raya dan Desa Kemuning Muda diambil secara sensus, yaitu semua lembaga pemasaran yang terlibat dalam pemasaran padi di lokasi penelitian.

Data yang digunakan dalam penelitian ini adalah data primer dan data sekunder. Data primer dikumpulkan melalui wawancara secara langsung dengan petani dan lembaga pemasaran padi yang terpilih sebagai sampel berdasarkan daftar

pertanyaan yang telah disiapkan. Data sekunder adalah data yang diperoleh melalui 
dokumen-dokumen atau laporan-laporan tertulis yang menyangkut dengan tujuan penelitian.

\section{Analisis Data}

\section{Saluran Pemasaran}

Saluran pemasaran dianalisis secara deskriptif, yaitu dengan melihat aliran pemasaran padi yang dilalui mulai dari produsen sampai ke konsumen.

\section{Analisis Struktur Pasar}

Struktur pasar dianalisis secara deskriptif, yaitu dengan menjelaskan (1) Menganalisis struktur pasar dengan menjelaskan jumlah pelaku pasar dan (2) Hambatan keluar masuk pasar. Selain itu struktur pasar juga dianalisis secara kuantitatif, yaitu menganalisis jumlah dan ukuran lembaga pemasaran dengan menghitung pangsa pasar (market share), konsentrasi rasio dan Indeks Herfindhal (HI).

Pangsa pasar (market share) menunjukkan bagian pasar yang dikuasai oleh suatu lembaga pemasaran. Pangsa pasar suatu lembaga pemasaran dapat dirumuskan sebagai berikut:

$$
\mathrm{MSi}=\frac{S i}{\text { Stot }} \times 100
$$

Keterangan:

MSi : Pangsa pasar suatu lembaga pemasaran (\%)

$\mathrm{S}_{\mathrm{i}} \quad$ : Jumlah penjualan lembaga pemasaran ke-i (Rp)

$\mathrm{S}_{\text {tot }}$ : Total penjualan seluruh lembaga pemasaran $(\mathrm{Rp})$

Kosentrasi rasio $(\mathrm{Kr})$ adalah perbandingan antara jumlah barang yang dibeli oleh pedagang tertentu dengan jumlah barang yang dijual oleh semua pedagang, kemudian dikalikan dengan 100\% (Martin, 1989).

$$
\mathrm{Kr}=\frac{\text { Jumlah barang yang dibeli oleh pedagang tertentu }}{\text { Jumlah barang yang dijual oleh semua pedagang }} \times 100 \%
$$

Apabila ada satu pedagang yang memiliki nilai Kr minimal 95\% maka pasar tersebut dikatakan sebagai pasar monopsoni. Apabila ada empat pedagang memiliki nilai $\mathrm{Kr}$ minimal $80 \%$ maka pasar tersebut dikatakan sebagai pasar oligopsoni konsentrasi tinggi. Apabila ada delapan pedagang memiliki nilai $\mathrm{Kr}$ minimal $80 \%$ 
maka pasar tersebut dikatakan sebagai pasar oligopsoni konsentrasi sedang (Hay dan Morris, 1991).

$$
\mathrm{IH}=(\mathrm{SI})^{2}+(\mathrm{S} 2)^{2}+\ldots+(\mathrm{Sn})^{2}
$$

Keterangan :

$\mathrm{S} 1, \mathrm{~S} 2, \ldots \mathrm{Sn}=$ pangsa pembelian padi dari pedagang ke $1,2, \ldots, \mathrm{n}$

Dengan kriteria :

Jika $\mathrm{IH}=1$ maka pasar padi mengarah pada pasar monopsoni

Jika IH = 0 maka pasar padi mengarah pada pasar persaingan sempurna

Jika $0<\mathrm{HI}<\mathrm{I}$ maka pasar padi mengarah pada pasar oligopsoni

\section{Analisis Perilaku Pasar}

Perilaku pasar dianalisis secara deskriptif dan kuantitatif. Analisis secara deskriptif yaitu menjelaskan praktik penentuan harga padi dan bentuk hubungan yang terjadi antara sesama lembaga pemasaran. Analisis secara kuantitatif dilakukan untuk melihat korelasi harga dan transmisi harga antara harga padi ditingkat petani dan harga padi di tingkat konsumen. Keeratan hubungan antara harga padi ditingkat petani dan harga padi di tingkat konsumen ditunjukkan oleh nilai koefisien korelasi.

Rumus koefisien korelasi:

$$
r=\frac{\left[n \sum X i Y i-\left(\sum X i\right)\left(\sum Y i\right)\right]}{\sqrt{\left[n \sum X^{2}-\left(\sum X i\right)^{2}\left[n \sum Y^{2}-\left(\sum Y i\right)^{2}\right]\right.}}
$$

Keterangan :

$\mathrm{r}=$ Korelasi harga padi ditingkat pabrik dan harga ojol ditingkat petani

$\mathrm{n}=$ Jumlah Sampel

$\mathrm{Xi}=$ Harga padi ditingkat konsumen akhir $(\mathrm{Rp} / \mathrm{Kg})$

$\mathrm{Yi}=$ harga padi ditingkat petani $(\mathrm{Rp} / \mathrm{Kg})$

Analisis transmisi harga akan memberikan informasi bagaimana keterpaduan pasar secara vertikal (Monce dan Petzel, 1984). Artinya, bagaimana perubahan harga yang terjadi di tingkat konsumen ditransmisikan ke tingkat produsen.

Tahapan analisis transmisi harga sebagai berikut:

1. Mengestimasi persamaan regresi yang menunjukkan bentuk hubungan antara harga padi di tingkat petani dengan harga padi di tingkat konsumen akhir.

46 Analisis Struktur Perilaku Dan Kinerja Pasar (Structure, Conduct And Market Performan) Komoditi Padi Di Desa Bunga Raya Dan Desa Kemuning Muda Kecamatan Bunga Raya Kabupaten Siak 
Persamaan regresi liniernya sebagai berikut :

Pf $=b_{o}+b_{1} P_{r}+e$

Keterangan :

$\mathrm{Pf}=$ Harga jual ditingkat petani $(\mathrm{Rp} / \mathrm{Kg})$

$\operatorname{Pr}=$ Harga jual ditingkat pedagang besar $(\mathrm{Rp} / \mathrm{Kg})$

bo $=$ Konstanta

b1 = Koefisien regresi

$\mathrm{e} 1=$ Galat

2. Menghitung elastisitas transmisi harga

Rumus elastisitas transmisi harga (Azaino,1982) sebagai berikut:

$\mathrm{Et}=\frac{d P f}{d P r} \cdot \frac{P r}{P f}$

$\mathrm{dPf} / \mathrm{dPr}=$ laju perubahan harga padi di tingkat petani

\section{HASIL DAN PEMBAHASAN}

\section{Saluran Pemasaran}

Saluran pemasaran dianalisis secara deskriptif, yaitu dengan melihat aliran yang dilalui oleh lembaga-lembaga pemasaran yang ada dalam proses pemasaran hasil produksi padi mulai dari petani hingga sampai ke konsumen. Panjang pendeknya saluran pemasaran akan berpengaruh pada harga yang akan diterima oleh petani sebagai produsen. Dari hasil penelitian diketahui ada tiga jenis saluran pemasaran padi, mulai dari produsen sampai ke konsumen.

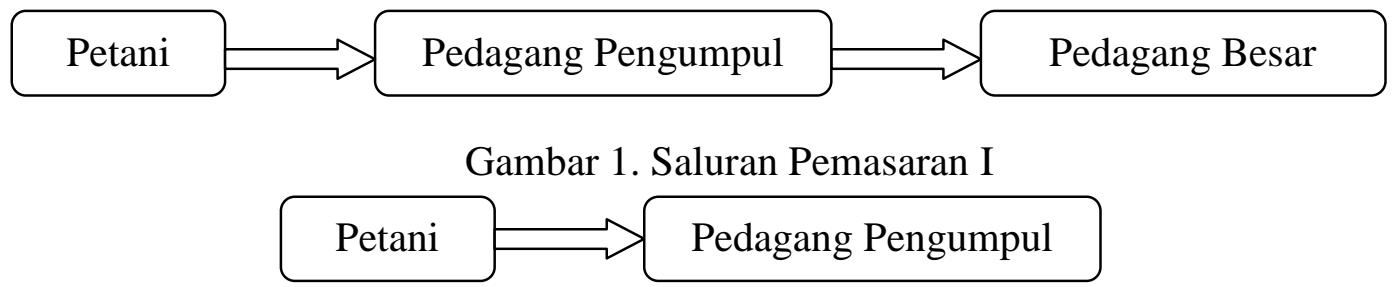

Gambar 2. Saluran Pemasaran II

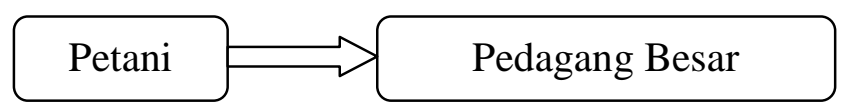

Gambar 3. Saluran Pemasaran III

47| Analisis Struktur Perilaku Dan Kinerja Pasar (Structure, Conduct And Market Performan) Komoditi Padi Di Desa Bunga Raya Dan Desa Kemuning Muda Kecamatan Bunga Raya Kabupaten Siak 
Dari hasil penelitian diketahui ada tiga saluran pemasaran padi di lokasi penelitian. Persentase petani yang menggunakan saluran pemasaran I sebanyak 22 orang $(30,56 \%)$. Persentase petani yang menggunakan saluran pemasaran II sebanyak 16 orang $(22,22 \%)$, sedangkan petani yang menggunakan saluran pemasaran III sebanyak 34 orang $(47,22 \%)$. Persentase petani responden di Desa Bunga Raya yang menjual melalui saluran pemasaran I sebanyak 18 orang (50,00\%), petani responden yang menjual melalui saluran pemasaran II sebanyak 7 orang $(19,44 \%)$ dan petani yang menjual melalui saluran pemasaran III sebanyak $(30,56 \%)$.

Persentase petani responden di Desa Kemuning Muda yang menjual melalui saluran pemasaran I sebanyak 4 orang $(11,11 \%)$, yang menjual melalui saluran pemasaran II sebanyak 9 orang $(25,00 \%)$ dan yang menjual melalui saluran pemasaran III sebanyak 23 orang $(63,89 \%)$.

\section{Analisis Deskriptif Struktur Pasar Padi}

\section{Jumlah Pelaku Pasar}

Jumlah petani padi di Desa Bunga Raya sebanyak 420 petani dan di Desa Kemuning Muda sebanyak 442 petani. Ada dua jenis lembaga pemasaran yaitu pedagang pengumpul dan pedagang besar. Pedagang pengumpul yang ada di Desa Bunga Raya sebanyak 12 orang dan pedagang besar sebanyak 5 orang. Sedangkan di Desa Kemuning Muda terdapat 6 orang pedagang pengumpul dan pedagang besar sebanyak 4 orang.

\section{Hambatan Keluar Masuk Pasar}

Hambatan keluar masuk pasar merupakan adanya kebebasan atau batasan bagi setiap orang untuk ikut dalam kegiatan pemasaran di suatu wilayah tertentu. Dari hasil penelitian yang dilakukan di Desa Bunga Raya terdapat kebebasan pedagang dari luar desa yang bisa masuk pasar. Hal ini disebabkan karena mayoritas para petani tidak memiliki keterikatan pada para pedagang, petani bebas menjual padinya ke pedagang yang mereka ingini. Sedangkan di Desa Kemuning Muda terdapat hambatan pedagang dari luar desa untuk masuk pasar. Hal ini disebabkan karena, petani dan pedagang di Desa Kemuning Muda memiliki hubungan dalam bentuk keterikatan karena petani sebelumnya telah berhutang dengan pedagang, baik dalam 
bentuk uang maupun barang, dalam berproduksi maupun dalam kebutuhan rumahtangga.

\section{Analisis Kuantitatif Struktur Pasar Padi di Desa Bunga Raya}

Analisis kuantitatif struktur pasar padi dapat di analisis dengan analisis market share, konsentrasi rasio dan indeks herfindhal. Nilai market share dan konsentrasi rasio pedagang pengumpul di Desa Bunga Raya., rata-rata market share dan konsentrasi rasio pedagang pengumpul adalah 0,08 dan 8,3\% yang artinya tidak ada satu pedagang pengumpul yang memiliki konsentrasi rasio diatas 95\%.Dilihat dari empat pedagang pengumpul dengan volume pembelian terbesar didapat market share sebesar 0,55 dan konsentrasi rasio sebesar 55,40\%, yang artinya dari empat pedagang pengumpul dengan volume pembelian terbesar nilai konsentrasi rasio yang diperoleh kecil dari $80 \%$.Kemudian dilihat dari delapan pedagang pengumpul dengan volume pembelian terbesar didapat market share sebesar 0,82 dan konsentrasi rasio sebesar $82,28 \%$, yang artinya dari delapan pedagang pengumpul dengan volume pembelian terbesar menunjukkan nilai konsentrasi rasio besar dari $80 \%$, dimana pedagang pengumpul memiliki kekuasaan yang sedang dalam mempengaruhi pasar padi. Hal ini mengacu kepada analisis struktur pasar menurut Hay dan Morris dalam Setiawan (2015), apabila ada delapan pedagang memiliki nilai konsentrasi rasio minimal $80 \%$ maka pasar mengarah pada pasar oligopsoni konsentrasi sedang. Nilai indeks herfindhal di Desa Bunga Raya didapat sebesar 0,1070 untuk pedagang pengumpul dan sebesar 0,2181 untuk pedagang besar, artinya nilai indeks herfindhal di Desa Bunga Raya lebih besar dari 0 dan lebih kecil dari 1 maka pasar padi yang terbentuk di Desa Bunga Raya adalah pasar oligopsoni.

\section{Analisis Kuantitatif Struktur Pasar Padi di Desa Kemuning Muda}

Analisis kuantitatif struktur pasar padi dapat di analisis dengan analisis market share, konsentrasi rasio dan indeks herfindhal. Nilai market share dan konsentrasi rasio pedagang pengumpul di Desa Kemuning Muda , rata-rata market share dan konsentrasi rasio pedagang pengumpul adalah 0,16 untuk market share dan $16,67 \%$ untuk konsentrasi rasio, yang artinya tidak ada satu pedagang pengumpul yang memiliki konsentrasi diatas $95 \%$.

49| Analisis Struktur Perilaku Dan Kinerja Pasar (Structure, Conduct And Market Performan) Komoditi Padi Di Desa Bunga Raya Dan Desa Kemuning Muda Kecamatan Bunga Raya Kabupaten Siak 
Kemudian dilihat dari market share dan konsentrasi rasio empat pedagang pengumpul dengan volume pembelian terbesar di Desa Kemuning Muda sebesar 0,84 untuk market share dan $84,47 \%$ untuk konsentrasi rasio, artinya dari empat pedagang pengumpul dengan volume pembelian terbesar didapat konsentrasi rasio diatas $80 \%$ dimana pedagang pengumpul memiliki tingkat kekuatan yang tinggi dalam mempengaruhi pasar padi. Nilai indeks herfindhal di Desa Kemuning Muda didapat sebesar 0,2095 untuk pedagang pengumpul dan sebesar 0,2506 untuk pedagang besar, artinya nilai indeks herfindhal di Desa Kemuning Muda lebih besar dari 0 dan lebih kecil dari 1 maka pasar padi yang terbentuk di Desa Kemuning Muda adalah pasar oligopsoni.

\section{Perilaku Pasar}

Perilaku pasar merupakan tingkah laku lembaga pemasaran yang menyesuaikan dengan struktur pasar yang terbentuk. Dalam penelitian ini akan disampaikan bagaimana sesungguhnya perilaku pasar yang terjadi pada pemasaran padi di Desa Bunga Raya dan Desa Kemuning Muda. Perilaku pasar padi dapat dijelaskan dengan praktik penentuan harga padi, nilai korelasi dan elastisitas transmisi harga padi. Petani yang ada telah mengetahui informasi tentang harga padi saat ingin menjual padi kepada para pedagang. Praktik penentuan harga padi yang terjadi di Desa Bunga Raya dan Desa Kemuning Muda Kecamatan Bunga Raya berbeda pada tiap desanya. Di Desa Bunga Raya petani dapat melakukan tawar menawar pada saat melakukan penjualan ke para pedagang, dan petani juga bebas menjual padi mereka ke pedagang yang menawarkan harga yang lebih tinggi, hal ini dikarenakan petani yang ada di Desa Bunga Raya tidak memiliki keterikatan kepada para pedagang. Sedangkan di Desa Kemuning Muda petani harus menerima dengan harga yang telah di tetapkan oleh para pedagang besar, karena mayoritas petani di Desa Kemuning Muda telah terikat dengan pedagang besar yang ada.Menurut Sugiarto dalam Wati (2015), koefisien korelasi adalah besaran yang dapat menunjukkan kekuatan hubungan antara dua variabel dan dapat diketahui berdasarkan nilai $r$ hasil analisis korelasi. Selanjutnya, besar nilai $r$ dapat diinterpretasikan untuk memperkirakan kekuatan hubungan korelasi. Harga di tingkat

50 Analisis Struktur Perilaku Dan Kinerja Pasar (Structure, Conduct And Market Performan) Komoditi Padi Di Desa Bunga Raya Dan Desa Kemuning Muda Kecamatan Bunga Raya Kabupaten Siak 
konsumen didekati dari harga jual beras di tingkat pedagang yang menjual dalam bentuk beras.

Tabel 5. Hasil analisis korelasi antara harga gabah maupun beras di tingkat petani dengan harga beras di tingkat konsumen

\begin{tabular}{cccccc}
\hline No & Desa & Uraian & Nilai $r$ & Kriteria Hubungan & Integrasi Pasar \\
\hline \multirow{3}{*}{1} & \multirow{2}{*}{ Bunga Raya } & GBP-Beras & 0,677 & Korelasi Sedang & Tidak Sempurna \\
& & GKG-Beras & 0,607 & Korelasi Sedang & Tidak Sempurna \\
& & Beras-Beras & 0,615 & Korelasi Sedang & Tidak Sempurna \\
\multirow{2}{*}{2} & \multirow{2}{*}{ Kemuning Muda } & GBP-Beras & 0,697 & Korelasi Sedang & Tidak Sempurna \\
& & Beras-Beras & 0,665 & Korelasi Sedang & Tidak Sempurna \\
\hline
\end{tabular}

Berdasarkan hasil analisis korelasi antara harga di tingkat petani dengan harga jual di tingkat pedagang maka nilai korelasi harga di tingkat petani di Desa Bunga Raya adalah 0,677 untuk petani yang menjual dalam bentuk GBP, 0,607 untuk petani yang menjual dalam bentuk GKG dan 0,615 untuk petani yang menjual dalam bentuk beras, di Desa Kemuning Muda adalah 0,697 untuk petani yang menjual dalam bentuk GBP dan 0,665 untuk petani yang menjual dalam bentuk beras. Hal ini menunjukkan jika nilai korelasi antara dua variabel berada antara 0,5 - 0,8 dikatakan terdapat hubungan yang bersifat sedang antara kedua variabel tersebut. Berarti korelasi antara harga di tingkat petani dengan harga di tingkat pedagang yang menjual dalam bentuk beras di Desa Bunga Raya dan Desa Kemuning Muda adalah berkorelasi sedang.

\section{Kinerja Pasar}

Margin pemasaran pada saluran pemasaran I diperoleh sebesar Rp. $955 / \mathrm{kg}$ di tingkat pedagang pengumpul dan sebesar Rp.4.734/kg di tingkat pedagang besar, total margin pemasaran pada saluran pemasaran I sebesar Rp.5.689/kg. Margin ini diperoleh dari rata-rata harga jual petani yang di dekati dari harga beli pedagang pengumpul dalam bentuk GBP (gabah basah panen) dengan harga sebesar Rp.4.732/kg kemudian pedagang pengumpul menjual dalam bentuk GKG (gabah kering giling) dengan harga sebesar Rp.5.187/kg kepada pedagang besar, pedagang besar menjual dengan harga sebesar Rp.9.921/kg dalam bentuk beras. Pada saluran pemasaran I didapat total biaya pemasaran di tingkat pedagang pengumpul sebesar

51 Analisis Struktur Perilaku Dan Kinerja Pasar (Structure, Conduct And Market Performan) Komoditi Padi Di Desa Bunga Raya Dan Desa Kemuning Muda Kecamatan Bunga Raya Kabupaten Siak 
Rp.700/kg, biaya pemasaran di tingkat pedagang pengumpul ini di dapat dari biaya transportasi, biaya bongkar dan muat, penyusutan 14\% dari GBP (gabah basah panen) ke GKG (gabah kering giling), biaya penjemuran dan biaya pulsa. Sedangkan di tingkat pedagang besar didapat total biaya pemasaran sebesar Rp.2.165/kg, biaya pemasaran di tingkat pedagang besar ini di dapat dari biaya transportasi, biaya supir, biaya bongkar, biaya muat, biaya pulsa, gaji karyawan, biaya perawatan mesin giling, biaya bahan bakar mesin giling, biaya pengemasan, pajak, dan penyusutan $26 \%$ dari GKG (gabah kering giling) ke beras. Penyusutan GBP menjadi beras didapat rendemen sebesar $60 \%$ dan total kehilangan sebesar 40\%, yang artinya dalam $100 \mathrm{~kg}$ GBP akan didapat $60 \mathrm{~kg}$ beras, penyusutan dari GBP menjadi GKG sebesar 14\% dan penyusutan dari GKG menjadi beras sebesar 26\%. Penyusutan gabah menjadi beras ini sama dengan penyusutan yang terdapat pada penelitian Ariati (2016).

Margin pemasaran pada saluran pemasaran II diperoleh sebesar Rp.1.777/kg ditingkat pedagang pengumpul. Margin ini diperoleh dari rata-rata harga jual petani yang didekati dari harga beli pedagang pengumpul dalam bentuk beras dengan harga sebesar Rp.8.127/kg kemudian pedagang pengumpul menjual dengan harga sebesar Rp.9.904/kg. Pada saluran pemasaran II didapat total biaya pemasaran ditingkat pedagang pengumpul sebesar Rp.548/kg. Margin pemasaran pada saluran pemasaran III diperoleh sebesar Rp.4.734/kg ditingkat pedagang besar. Margin ini diperoleh dari rata-rata harga jual petani yang didekati dari harga beli pedagang besar dalam bentuk GKG (gabah kering giling) dengan harga sebesar Rp.5.187/kg kemudian pedagang besar menjual dalam bentuk beras dengan harga sebesar Rp.9.921/kg. Pada saluran pemasaran III didapat total biaya pemasaran ditingkat pedagang besar sebesar Rp.2.165/kg. Margin pemasaran di Desa Bunga Raya dilihat dari tiga saluran pemasaran yaitu saluran pemasaran I didapat margin sebesar Rp.955/kg di tingkat pedagang pengumpul dan margin di tingkat pedagang besar sebesar Rp.4.734/kg total margin pada saluran pemasaran I sebesar Rp.5.689/kg. Saluran pemasaran II didapat margin sebesar Rp.1.777/kg di tingkat pedagang pengumpul. Saluran pemasarn III didapat margin sebesar Rp.4.734/kg di tingkat pedagang besar.

Margin pemasaran pada saluran pemasaran I diperoleh sebesar Rp.937/kg ditingkat pedagang pengumpul dan sebesar Rp.4.684/kg ditingkat pedagang besar, 
total margin pemasaran pada saluran pemasaran I sebesar Rp.5.621/kg. Margin ini diperoleh dari rata-rata harga jual petani yang didekati dari harga beli pedagang pengumpul dalam bentuk GBP (gabah basah panen) dengan harga sebesar Rp.4.238/kg kemudian pedagang pengumpul menjual dalam bentuk GKG (gabah kering giling) dengan harga sebesar Rp.5.208/kg kepada pedagang besar, pedagang besar menjual dengan harga sebesar Rp.9.892/kg. Pada saluran pemasaran I didapat total biaya pemasaran ditingkat pedagang pengumpul sebesar Rp.703/kg, biaya pemasaran ditingkat pedagang pengumpul ini didapat dari biaya transportasi, biaya bongkar dan muat, penyusutan 14\% dari GBP (gabah basah panen) ke GKG (gabah kering giling), biaya penjemuran dan biaya pulsa. Sedangkan di tingkat pedagang besar didapat total biaya pemasaran sebesar Rp.2.134/kg, biaya pemasaran ditingkat pedagang besar ini didapat dari biaya transportasi, biaya supir, biaya bongkar, biaya muat, biaya pulsa, gaji karyawan, biaya perawatan mesin giling, biaya bahan bakar mesin giling, biaya pengemasan, pajak, dan penyusutan 26\% dari GKG (gabah kering giling) ke beras. Penyusutan GBP menjadi beras didapat rendemen sebesar $60 \%$ dan total kehilangan sebesar 40\%, yang artinya dalam $100 \mathrm{~kg}$ GBP akan didapat $60 \mathrm{~kg}$ beras, penyusutan dari GBP menjadi GKG sebesar $14 \%$ dan penyusutan dari GKG menjadi beras sebesar 26\%. Penyusutan gabah menjadi beras ini sama dengan penyusutan yang terdapat pada penelitian Ariati (2016).Margin pemasaran pada saluran pemasaran II diperoleh sebesar Rp.1.758/kg ditingkat pedagang pengumpul. Margin ini diperoleh dari rata-rata harga jual petani yang didekati dari harga beli pedagang pengumpul dalam bentuk beras dengan harga sebesar Rp.8.121/kg kemudian pedagang pengumpul menjual dengan harga sebesar Rp.9.879/kg. Pada saluran pemasaran II didapat total biaya pemasaran ditingkat pedagang pengumpul sebesar Rp.541/kg, biaya pemasaran ditingkat pedagang pengumpul ini didapat dari biaya transportasi, biaya bongkar dan muat, biaya pengemasan, biaya bahan bakar rice miling mobile, biaya perawatan, upah karyawan dan biaya pulsa.

Margin pemasaran pada saluran pemasaran III diperoleh sebesar Rp.1.802/kg ditingkat pedagang besar. Margin ini diperoleh dari rata-rata harga jual petani yang didekati dari harga beli pedagang besar dalam bentuk beras dengan harga sebesar Rp.8.098/kg kemudian pedagang besar menjual dalam bentuk beras dengan harga

53 Analisis Struktur Perilaku Dan Kinerja Pasar (Structure, Conduct And Market Performan) Komoditi Padi Di Desa Bunga Raya Dan Desa Kemuning Muda Kecamatan Bunga Raya Kabupaten Siak 
sebesar Rp.9.900/kg. Pada saluran pemasaran III didapat total biaya pemasaran ditingkat pedagang besar sebesar Rp.575/kg, yang terdiri dari biaya transportasi, biaya supir, biaya bongkar, biaya muat, pulsa, gaji karyawan, perawatan mesin giling, bahan bakar mesin giling, pengemasan, pajak. Margin pemasaran di Desa Kemuning Muda dilihat dari tiga saluran pemasaran yaitu saluran pemasaran I didapat margin sebesar Rp.937/kg di tingkat pedagang pengumpul dan margin di tingkat pedagang besar sebesar Rp.4.684/kg total margin pada saluran pemasaran I sebesar Rp.5.621/kg. Saluran pemasaran II didapat margin sebesar Rp.1.758/kg di tingkat pedagang pengumpul. Saluran pemasarn III didapat margin sebesar Rp.1.802/kg di tingkat pedagang besar.

Keuntungan lembaga pemasaran di Desa Bunga Raya.Total keuntungan yang diterima oleh lembaga pemasaran di Desa Bunga Raya dilihat dari saluran pemasaran yang digunakan oleh lembaga pemasaran, pada saluran pemasaran I pedagang pengumpul memperoleh keuntungan sebesar Rp.255/kg dan pedagang besar sebesar Rp.2.569/kg, total keuntungan pada saluran pemasaran I sebesar Rp.2.824/kg. Keuntungan pada saluran pemasaran II pedagang pengumpul memperoleh keuntungan Rp.1.229/kg, pada saluaran pemasaran II hanya ada satu lembaga pemasaran yang terlibat, yaitu pedagang pengumpul. Keuntungan pada saluran pemasaran III pedagang besar memperoleh keuntungan sebesar Rp. $2.569 / \mathrm{kg}$, pada saluran pemasaran III hanya ada satu lembaga pemasaran yang terlibat yaitu pedagang besar.

Total keuntungan yang diterima oleh lembaga pemasaran di Desa Kemuning Muda dilihat dari saluran pemasaran yang digunakan oleh lembaga pemasaran, pada saluran pemasaran I pedagang pengumpul memperoleh keuntungan sebesar Rp.235/kg dan pedagang besar sebesar Rp.2.550/kg, total keuntungan pada saluran pemasaran I sebesar Rp.2.785/kg. Keuntungan pada saluran pemasaran II pedagang pengumpul memperoleh keuntungan Rp.1.217/kg, pada saluaran pemasaran II hanya ada satu lembaga pemasaran yang terlibat, yaitu pedagang pengumpul. Keuntungan pada saluran pemasaran III pedagang besar memperoleh keuntungan sebesar Rp.1.227/kg, pada saluran pemasaran III hanya ada satu lembaga pemasaran yang terlibat yaitu pedagang besar. Persentase keuntungan pemasaran di tingkat pedagang

54 Analisis Struktur Perilaku Dan Kinerja Pasar (Structure, Conduct And Market Performan) Komoditi Padi Di Desa Bunga Raya Dan Desa Kemuning Muda Kecamatan Bunga Raya Kabupaten Siak 
pengumpul adalah 22,41\% di Desa Bunga Raya dan di Desa Kemuning Muda sebesar 27,77\%. Sedangkan di tingkat pedagang besar adalah 77,59\% di Desa Bunga Raya dan di Desa Kemuning Muda sebesar 72,23\%.

\section{KESIMPULAN DAN SARAN}

\section{Kesimpulan}

1. Struktur pasar padi di Desa Bunga Raya dan di Desa Kemuning Muda mengarah pada pasar persaingan tidak sempurna.

2. Perilaku pasar padi di Desa Bunga Raya dan Desa Kemuning Muda mengarah pada pasar persaingan tidak sempurna. Terdapat korelasi sedang antara harga padi di tingkat petani dengan harga padi di tingkat konsumen. Sedangkan transmisi harga antara pasar di tingkat petani dengan harga pasar di tingkat konsumen menunjukan nilai koefisien elastisitas transmisi harga kecil dari satu.

3. Kinerja pasar padi di Desa Bunga Raya dan Desa Kemuning Muda yang dilihat dari margin pemasaran, biaya pemasaran dan keuntungan di tiap lembaga pemasaran padi di Desa Bunga Raya dan Desa Kemuning Muda di peroleh keuntungan terbesar oleh pedagang yang melakukan lebih banyak fungsi pemasaran dengan mengeluarkan lebih banyak biaya pemasaran.

\section{Saran}

1. Diharapkan adanya suatu lembaga yang dapat membantu petani dalam hal permodalan agar petani dapat melakukan usahatani yang berkelanjutan.

2. Perlu adanya peran pemerintah yang mengatur tentang ketersediaan sarana dan prasarana yang mendukung bagi para pelaku usahatani padi.

\section{DAFTAR PUSTAKA}

Anonim. 2016. Instruksi Peresiden Republik Indonesia Nomor 5 Tahun 2015 Tentang Kebijakan Pengadaan Gabah/Beras dan Penyaluran Beras Oleh Pemerintah. http : // bkp. pertanian. go. Id / tinymcpuk / gambar / file / Inpres _Nomor_5_Tahun_2015.pdf. Diakses pada tanggal 17 Januari 2016.

Ariaty W. 2016. Analisis Marjin Pemasaran Agroindustri Beras di Kecamatan Bunga Raya Kabupaten Siak. Skripsi Fakultas Pertanian Universitas Riau. Pekanbaru.

BPS Kabupaten Siak. 2015. Siak Dalam Angka 2015. Badan Pusat Statistik Kabupaten Siak.

55 Analisis Struktur Perilaku Dan Kinerja Pasar (Structure, Conduct And Market Performan) Komoditi Padi Di Desa Bunga Raya Dan Desa Kemuning Muda Kecamatan Bunga Raya Kabupaten Siak 
BPS Provinsi Riau. 2015. Riau Dalam Angka 2015. Badan Pusat Statistik Provinsi Riau.

Dinas Tanaman Pangan dan Holtikultura Kabupaten Siak. 2015. Tanaman Pangan dan Holtikultura. Kabupaten Siak

Hay, D. A \& Moris, D.,J. 1991. Industrial Economic \& Organization, Theory \& Evidence. Second Edition. Oxford University Press.

Martin, S. 2002. Industrial Economics: Economic Analysis \& Public Policy. Second Edition. New York: Mac. Milan.

Purcell W.D. 1979. Agricultural Marketing, System, Coordination, Cash and Future Price. Prentice Hall Compeny. Virginia.

Setiawan, Jeny. 2015. Pemasaran Karet (Kajian Struktur, Prilaku dan Penampilan Pasar) di Kabupaten Kuantan Singingi Provinsi Riau. Skripsi Fakultas Pertanian Universitas Riau.

Sudiyono, A. 2001. Pemasaran Pertanian. Penerbit Universitas Muhammadiyah Malang (UMM Perss). Malang.

Syahza, A. 2003 Paradigma Baru Pemasaran Produk Pertanian Berbasis Agribisnis di Daerah Riau dalam Jurnal Ekonomi, 8(1):1-11

Wati, Widia. 2015. Analisis SCP (Strukture, Conduct, and Performance) Pasar Ojol Di Kecamatan Kampar Kiri Kabupaten Kampar. Skripsi Jurusan Agribisnis Fakultas Pertanian Universitas Riau. 